\title{
Introduction and Geological Setting of the Iberian Pyrite Belt
}

\author{
C. Inverno, A. Díez-Montes, C. Rosa, J. García-Crespo, \\ J. Matos, J.L. García-Lobón, J. Carvalho, F. Bellido, \\ J.M. Castello-Branco, C. Ayala, M.J. Batista, F. Rubio, \\ I. Granado, F. Tornos, J.T. Oliveira, C. Rey, Vítor Araújo, \\ T. Sánchez-García, Z. Pereira, P. Represas, A.R. Solá \\ and P. Sousa
}

\begin{abstract}
The $250 \times 20-70 \mathrm{~km}$ Iberian Pyrite Belt (IPB) is a Variscan metallogenic province in SW Portugal and Spain hosting the largest concentration of massive sulphide deposits worldwide. The lowermost stratigraphic unit is the early Givetian to late Famennian-Strunian (base unknown) PhylliteQuartzite Group (PQG), with shales, quartz-sandstones, quartzwacke siltstones, minor conglomerate and limestones at the top. The PQG is overlain by the Volcanic Sedimentary Complex (VSC), of late Famennian to mid-late Visean age, with a lower part of mafic volcanic rocks, rhyolites, dacites and dark shales, hosting VHMS deposits on top (many times capped by a jasper/chert layer), and an upper part, with dark, purple and other shales and volcanogenic/volcaniclastic rocks, carrying Mn oxide deposits. The VSC is covered by the thousands of meters thick Baixo Alentejo Flysch Group of late Visean to Moscovian age. The VSC
\end{abstract}

C. Inverno $(\bowtie) \cdot$ J. Carvalho $\cdot$ M.J. Batista I. Granado · J.T. Oliveira · P. Represas · A.R. Solá Laboratório Nacional de Energia e Geologia (LNEG), Estrada Portela-Zambujal, Apartado 7586, 2610-999 Alfragide, Portugal e-mail: carlos.inverno@lneg.pt

A. Díez-Montes · J. García-Crespo · J.L. García-Lobón F. Bellido - C. Ayala - F. Rubio - C. Rey

T. Sánchez-García

Instituto Geológico y Minero de España (IGME),

C/ Ríos Rosas, 23, 28003 Madrid, Spain

C. Rosa

Empresa de Desenvolvimento Mineiro SA (EDM), Rua Sampaio e Pina 13 DTO, 1070-248 Lisboa, Portugal

J. Matos · P. Sousa

LNEG, Rua Frei Amador Arrais, 39 r/c, Apartado 104, 7801-902 Beja, Portugal
J.M. Castello-Branco

Geology and Geotechnics Consultores Lda., Rua Cunha Júnior, 41b Sala 1.6, 4250-186 Porto,

Portugal

C. Ayala

Institute of Earth Sciences Jaume Almera (CSIC), C/ Lluís Solé i Sabarís, s/n, 08028 Barcelona, Spain

F. Tornos

CSIC-INTA, Ctra. Ajalvir, km 4, 28850 Torrejón de Ardoz, Spain

V. Araújo

Rua Sub-carreira, 575, 4815-517 Vizela, Portugal

Z. Pereira

LNEG, Rua da Amieira, Apartado 1089, 4466-901

S. Mamede Infesta, Portugal 
comprises a bimodal submarine volcanic succession, with VHMS deposits spatially associated to dacites and rhyolites corresponding to effusive/explosive lava-cryptodome-pumice cone volcanoes. The lava/domes consist of coherent lithofacies surrounded by clast-rotated hyaloclastite breccia and minor autobreccia, with massive VHMS ore at the top of the felsic effusive units and stockworks in the autoclastic and pyroclastic breccias. The eastern IPB rocks are intruded by the voluminous Sierra Norte Batholith (tonalite-trondhjemite-granodiorite, TTG series). Felsic volcanic rocks (dacite to high-silica rhyolite) predominating over basalts and dolerites, belong to the calc-alkaline series and plot mostly in the within-plate field in tectonic discriminative diagrams. Several periods of volcanism, from 384 to $359 \mathrm{Ma}$ are recognized. Dacites and rhyolites exhibit $\mathrm{Nd}$ and $\mathrm{Sr}$ enrichment, typical of a crustal signature, and their overall geochemistry suggests generation by fractionation/partial melting of amphibolites at low pressure. Trace elemental modelling of the basic rocks, involving tholeiitic lavas and alkaline basaltic lavas and dolerites, points to mixing between $\mathrm{E}$ - and N-MORB and assimilation of crustal material. Variscan NW-SE/W-E-trending and SW- or S-verging folds (with NE- or N-dipping planar cleavage) and thrusts, occur in west-central and eastern IPB, respectively. In late to post-Variscan time strike-slip oblique faults formed, either N-S to NNW-SSE or NE-SW to ENE-WSW, dextral or sinistral (both extensional), respectively. The first set hosts late Variscan $\mathrm{Cu}-\mathrm{Pb}-\mathrm{Ba}$ veins and Mesozoic(?) dolerite dykes. IPB contains over 90 VHMS deposits, estimated before erosion at $>1700$ Million tonnes (Mt), with 14.6 Mt Cu, 34.9 Mt Zn, 13.0 Mt Pb, 46,100 t Ag, 880 t Au and many other metals, particularly Sn. Eight of these are giant ( $\geq 100 \mathrm{Mt})$ VHMS deposits, namely Rio Tinto, Tharsis, Aznalcóllar-Los Frailes, Masa Valverde, Sotiel-Migollas and La Zarza (Spain) and Neves Corvo and Aljustrel (Portugal). The VHMS deposits are of the felsic-siliclastic type and mostly of the $\mathrm{Zn}-\mathrm{Pb}-\mathrm{Cu}$ and $\mathrm{Zn}-\mathrm{Cu}-\mathrm{Pb}$ metal content types. The deposits range in thickness from $1 \mathrm{~m}$ to tens of meters (plus increase from tectonic stacking) and up to a few kilometers in extension, and many are underlain by large stockwork zones. Their age is either Strunian (palynological age) in the southern IPB or mostly Tournaisian in the northern IPB. The major massive ore minerals are pyrite, sphalerite, chalcopyrite, galena (and cassiterite at Neves Corvo), also present with dominant quartz-chlorite-sericite-carbonate in the stockwork ore. Sericite and chlorite were also formed from additional alteration in the hanging wall rocks. Metal zonation in most VHMS deposits consists of a $\mathrm{Cu}$-rich stockwork and base of the massive ore, with $\mathrm{Zn}-\mathrm{Pb}$ massive ore above and extending laterally. S-, O-, $\mathrm{H}$ - and $\mathrm{C}$-isotope data indicate that ore-forming fluids contain predominant or exclusive modified seawater. A magmatic fluid contribution to the dominant seawater has been proposed for some deposits. The deposits are exhalative or formed by shallow subsurface replacement of either muds/shales or coherent felsic volcanic rocks. 


\subsection{Geologic Setting}

The metallogenic province known as the Iberian Pyrite Belt (IPB), in southwestern Portugal and Spain, is one of the domains of the South Portuguese Zone in the Iberian Massif (Oliveira 1990; Fig. 9.1). It is a $250 \mathrm{~km}$ long and $20-70 \mathrm{~km}$ wide belt, bounded to the north by the Pulo do Lobo Domain (PLD) and overlain by the Baixo Alentejo Flysch Group (BAFG) also designated as Culm. The South Portuguese Zone (SPZ) constitutes the southernmost paleogeographic and paleotectonic unit of the European Variscan orogen.

The PLD, tectonically structured as a Variscan antiform (Pereira et al. 2006), is a succession of highly sheared phyllites intercalated with MORB type basalts in the lower part (Pulo do Lobo Formation), which grades into the south to the overlying highly deformed sandstone dominated Atalaia Formation. The age of these units is not well constrained, the Pulo do Lobo Formation, based on U-Pb zircon ages (Braid et al. 2011) is suggested to be middle-late(?) Silurian to middle Devonian in age. These units are overlain in both limbs of the antiform by a flyschoid sequence which age ranges from the upper Frasnian to the upper Famennian (Pereira et al. 2006, 2008). Various tectonic interpretations have been suggested for the PLD: (i) an accretionary prism in close association with a subduction zone dipping to the north below the Ossa-Morena Zone as a consequence of the Rheic Ocean closure (Munhá et al. 1986a; Quesada et al. 1994; Pereira et al. 2006; Ribeiro et al. 2007); (ii) an independent terrane (Ribeiro et al. 1990); (iii) an escaped crustal block that resulted from the Iberia indentation with Laurussia, responsible for the generation of the Ibero-Armorican arc (Braid et al. 2011) and, finally, (iv) the infilling of a deep extensional basin between the SW border of the Ossa Morena Zone and the Iberian Pyrite Belt (Pereira et al. 2012a).

The IPB is one of the most outstanding ore provinces of the world. It represents the largest crustal anomaly in sulphur (Laznicka 1999) and arguably hosts the largest concentration of volcanogenic massive sulphide deposits worldwide, including several world-class and giant deposits such as Río Tinto in Spain and Neves Corvo in Portugal (Tornos 2006). Mining in the IPB is documented from $4000 \mathrm{BC}$ and the exploitation

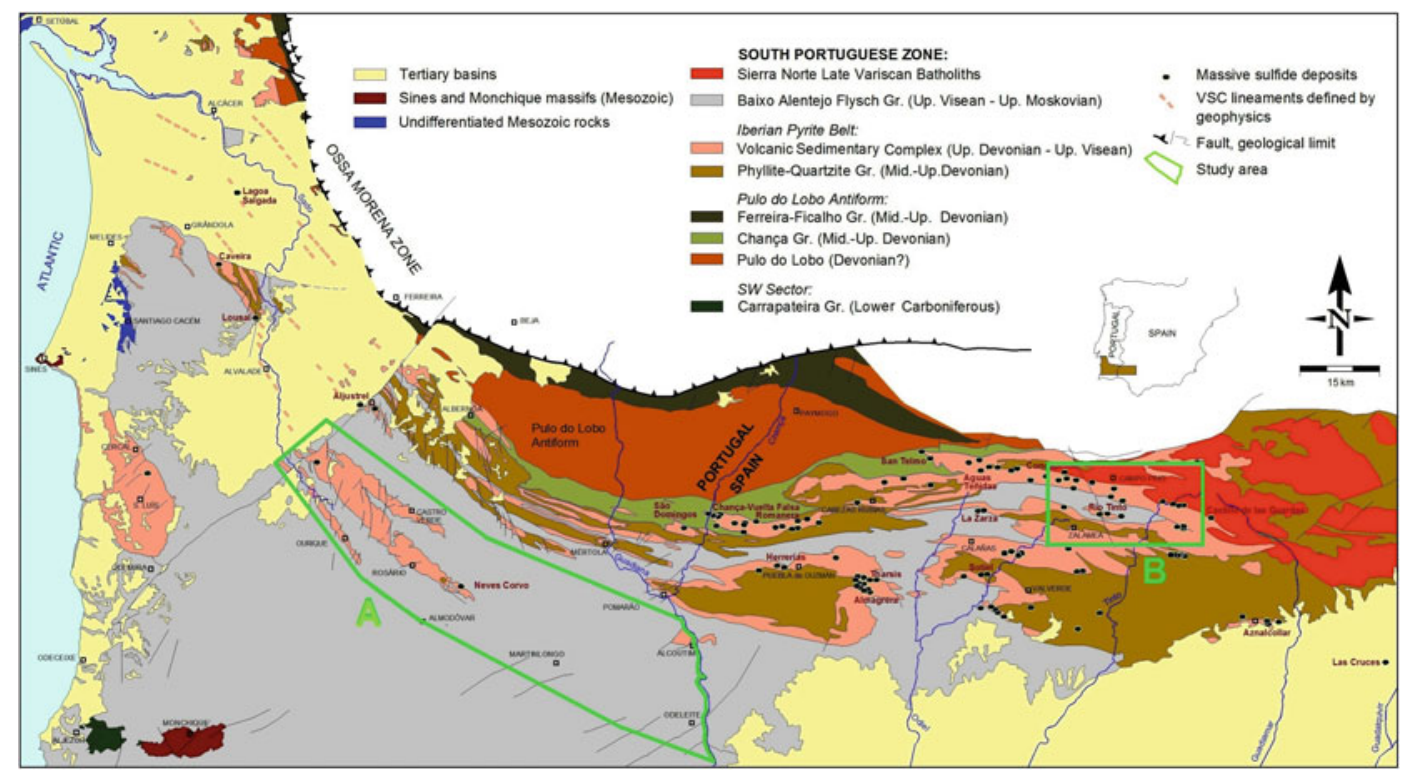

Fig. 9.1 Regional geology of the South Portuguese Zone, including the Iberian Pyrite Belt and associated VHMS deposits and showing location of the Neves Corvo $(A)$ and Río Tinto $(B)$ project areas 
has been oriented to the extraction of precious $(\mathrm{Au}, \mathrm{Ag})$ and base $(\mathrm{Cu}, \mathrm{Zn}, \mathrm{Pb})$ metals and pyrite.

The IPB is composed of three major lithostratigraphic units, the Phyllite Quartzite Group (PQG), the Volcanic Sedimentary Complex (VSC), which is the focus of the present work, and the Baixo Alentejo Flysch Group (BAFG) (Schermerhorn 1971; Oliveira 1983). General syntheses on the IPB include those of Strauss et al. (1977), Routhier et al. (1980), IGME (1982), Barriga (1990), Sáez et al. (1996), Leistel et al. (1998), Carvalho et al. (1999), Junta de Andalucía (1999), Tornos et al. (2000), Tornos (2006). Other general studies deal with stratigraphy (Oliveira 1990; Pereira et al 2007), volcanism (Munhá 1983; Mitjavila et al. 1997; Thiéblemont et al. 1998), structure and regional metamorphism (e.g., Munhá 1990; Silva et al. 1990; Quesada 1998) or the facies architecture of the volcano-sedimentary complex (Soriano and Martí 1999; Junta de Andalucía 1999; Rosa 2007).

The Baixo Alentejo Flysch Group well exposed in SW Iberia, represents the infill of a foreland basin, which was developed following a compressive Variscan tectonic inversion that occurred during the upper Visean and lasted until the upper Moscovian (Oliveira et al. 1979; Silva et al. 1990; Pereira et al. 2008). The sandy/shale turbidites that filled the foreland basin had their multiple sources in the SW border of the Ossa Morena Zone, in the IPB and in the Avalonia plate (Jorge et al. 2012).

\subsection{Stratigraphy}

The lowermost lithostratigraphic unit in IPB is the Phyllite-Quartzite Group (PQG), underlying the Volcanic Sedimentary Complex (VSC). The PQG is largely dominated by dark shales in which there are interbedded packets of quartzsandstones, quartzwacke siltstones, rare conglomerates and carbonate lenses and nodules at the top. The quartz-sandstone beds are predominantly massive or show less frequent parallel lamination, large scale cross bedding and graded bedding. The siltstones are thin-bedded and current ripples are common. The quartzwackes are massive or show rare graded bedding.

In the northern branch of the IPB (Oliveira 1990) the PQG lithologies are organized in allochthonous tectonic sheets and the sandstones are frequently disrupted in lenses, blocks and pebbles of variable size, which make sedimentological studies difficult. This disruption is mainly caused by tectonism but, at least in part, was formed by large debris flows (Oliveira 1990; Moreno et al. 1995). Detailed palynostratigraphic studies of drill-holes and sections, complemented by regional geological studies, from the northern branch of IPB, indicate that the age of PQG unit spans from the upper Famennian to the upper Strunian (Upper Devonian). Furthermore, it confirms that here the PQG tectonically overlies the VSC sequence.

In the southern branch of the IPB the PQG lithologies are associated with antiformal structures. In spite of the tectonic deformation, the PQG lithologies appear organized in a very thick megasequence (up to $2000 \mathrm{~m}$ thick), in which the quartz-rich sandstones are more abundant at its upper part. The age of the PQG, based on detailed palynostratigraphic data, ranges from the lower Givetian of middle Devonian (Junta de Andalucía 1999; Pereira et al. 2008, 2009), in the WNW region of the IPB, Frasnian (Rodríguez et al. 2002; López et al. 2004), to the late Famennian and Strunian of the Upper Devonian in the entire IPB (Junta de Andalucía 1999; Rodríguez et al. 2002; Pereira et al. 2008). Palynomorph assemblages include well to moderately preserved acritarchs and prasinophytes, substantiating a shallow marine depositional environment for these rocks (Junta de Andalucía 1999; Pereira et al. 2008). Sedimentological studies in the Virgen de la Peña region (Moreno and Sáez 1990) and at Berrocal (Jorge et al. 2007) prove that the PQG sediments were deposited in shallow water marine platform environments, confirming palynologic data.

A particular characteristic of this south branch is the occurrence of a decametric thick lithological unit composed of dark shales with intercalations of limestone lenses and nodules at the top of the PQG megasequence. The limestones 
display excellent faunas of conodonts of late Famennian age (Boogaard 1963; Boogaard and Schermerhorn 1980, 1981).

The stratigraphically overlying VSC is dominated by shales and thin-bedded siltstones, and minor volcanogenic sedimentary rocks. The latter sedimentary units encompass dominant felsic volcanic rocks (rhyolites, rhyodacites and dacites), mafic volcanic rocks (basalts and dolerites), either in the foot- or hanging wall of the volcanogenic massive sulphide (VHMS) deposits, and minor andesites. The felsic rocks occur dominantly as lava/dome complexes, associated with minor pyroclastic flows and intrusions (Martí Molist et al. 1994; Soriano and Martí 1999; Junta de Andalucía 1999; Rosa et al. 2010a). The massive sulphide ore deposits and related hydrothermal systems, when present, usually occur at the top of felsic volcanic rocks in close association with black shales and may have a relatively thin layer of jasper/carbonates commonly at the top (Leca et al 1983; Barriga and Kerrich 1984; Carvalho et al. 1999). Most of the black mudstones that enclose the massive sulphide ores are of late Strunian age (e.g., Neves Corvo, Lousal, Caveira, Montinho, Aznalcóllar and Tharsis) based on their palynomorph assemblages (Pereira et al. 1996, 2008, 2012b; González et al. 2002; Oliveira et al. 2004; Matos et al. 2011).

A notable characteristic of this complex is the occurrence of a decametric thick level of purple, green and grey shales at its upper part. This level occurs throughout the IPB at the same stratigraphic position, which is an excellent marker for lateral correlation and mapping purposes. Palynostratigraphic data allowed dating the VSC at late Famennian to mid late Visean (Oliveira et al. 2004, 2005; Pereira et al. 2007). Several chronostratigraphic gaps were identified in the Portuguese part of the IPB succession, the most important being the absence of Tournaisian sedimentary rocks, e.g. in the Neves-Corvo area (Oliveira et al. 2004). The occurrence of marine fossils (mainly prasinophytes algae and conodonts of early late Visean age) in the VSC indicates that it formed in a submarine setting. The VSC thickness is variable across the basin and reaches $1300 \mathrm{~m}$ in the proximity of volcanic centres. In many regions of the IPB, the VSC has been divided into several lithostratigraphic units. The dating of all these units across the IPB is a fundamental step towards a regional stratigraphic correlation and consequently better understanding of the IPB basin development. This approach is essential for massive sulphide ore exploration.

The eastern IPB rocks are intruded by large volumes of subvolcanic-plutonic rocks of the Sierra Norte Batholith (SNB) (Simancas 1983; De la Rosa 1992). The SNB includes three types of geochemical associations, mafic rocks (gabbrodiorite) with ultramafic cumulates, subvolcanic TTG intrusions, tonalite, trondhjemite and granodiorite (Schütz et al. 1987; Halsall 1989; Díez-Montes and Bellido-Mulas 2008; DíezMontes et al. 2011) with an age range of 335$355 \mathrm{Ma}$ (Dunning et al. 2002; Barrie et al. 2002; Gladney et al. 2014, in press), and aluminopotassic granitoid plutons that intruded the TTG group (Díez-Montes and Bellido-Mulas 2008). There is common evidence of mingling between the TTG and the mafic rocks.

$\mathrm{U}-\mathrm{Pb}$ dating of zircons has been carried out in several places in the IPB (Nesbitt et al. 1999; Barrie et al. 2002; Dunning et al. 2002; Rosa et al. 2009; Valenzuela et al. 2011). The age determinations were predominantly made of felsic rocks (rhyolites and rhyodacites). More recently, new data was obtained for felsic rocks of the Neves Corvo-Rosário Antiform, Portugal, and five episodes of volcanism were recognized, from 359 to 384 Ma. This means that in these regions high heat flow was maintained for $\sim 30 \mathrm{Ma}$ and may have been responsible for the generation and maintenance of hydrothermal convective cells that contributed to the genesis of the massive sulphide ores (Oliveira et al. 2013). However, a better age constraint of the lithological sequences is still needed.

The VSC was formed as a consequence of a Famennian to mid-late Visean extensional tectonic regime that disrupted the siliciclastic platform in extensional graben-type basins (Oliveira 1990) related to continent (South Portuguese Zone)-continent (Ossa Morena Zone) oblique collision (Silva et al. 1990; Quesada 1998; 
Tornos et al. 2005). From a paleogeographic point of view it has been suggested that the PQG and the VSC were situated at the eastern margin of the Avalonia plate (Oliveira and Quesada 1998; Ribeiro et al. 2007) or that they have affinities with the Meguma terrane (Braid et al. 2011) before their integration in the Variscan Chain following the Rheic Ocean closure and culmination of the amalgamation of the Pangea supercontinent by the collision between Gondwana and Laurussia during the late Palaeozoic.

\subsection{Physical Volcanology}

The Volcanic Sedimentary Complex (VSC) of the IPB comprises a bimodal volcanic submarine succession that together with accompanying sedimentary rocks hosts one of the largest concentrations of massive sulphide deposits in the earth's crust. The massive sulphide deposits are considered to be spatially associated to felsic (dacitic to rhyolitic) volcanic units (Routhier et al. 1980; Barriga 1990; Barriga et al. 1997), black shales (Barriga et al. 1997; Tornos 2006), or both (Barriga et al. 1997; Sáez et al. 1999; Relvas 2000; Tornos 2006). The volcanic rocks are only approximately $25 \%$ of the stratigraphic record of the VSC, the remaining $75 \%$ are mainly mudstone.

Studies of the volcanic facies architecture of the VSC in several areas of the IPB interpreted the felsic volcanic centres as constructed by a combination of effusive and explosive volcanic units and high-level intrusions (e.g., Martí Molist et al. 1994; Soriano and Martí 1999; Boulter 1993, 1996; Donaire et al. 2002; Rosa et al. 2008; Valenzuela et al. 2011). Recently, a regional study of the volcanic and sedimentary facies architecture in SW Iberia pointed out that the felsic volcanic centres correspond to "lavacryptodome-pumice cone volcanoes" (Junta de Andalucía 1999; Rosa et al. 2010a). These volcanoes have formed in submarine setting at variable water depth and can be up to $8 \mathrm{~km}$ laterally and $800 \mathrm{~m}$ thick (Rosa et al. 2010a).
The volcanic centres consist of a variety of lithofacies that correspond to felsic lavas and domes, pyroclastic units and intrusions; and minor mafic lavas, locally showing pillows, and intrusions. The felsic lavas/domes are dominant and can occur at several stratigraphic levels. The pyroclastic units are mostly lava/dome derived and less voluminous than the lava/domes. The intrusions are minor and occur as cryptodomes, partly extrusive cryptodomes and sills. The architecture of the felsic centres throughout the IPB comprises different combinations and proportions of these units (Rosa et al. 2010a).

The lava/domes typically consist of thin intervals of coherent lithofacies that are surrounded by very thick intervals of in situ and clast-rotated hyaloclastite breccia and minor autobreccia. The coherent lithofacies are characterized by microcrystalline groundmass textures and may also show spherulites and lithophysae. The hyaloclastite breccias typically comprise angular clasts with planar and curviplanar margins and abundant perlite fractures in the groundmass. These breccias are abundant throughout the VSC and indicate that the felsic effusive units had glassy groundmasses that underwent significant quenching in contact with water. Units of bedded hyaloclastite derived from the clastic components of the lava/domes occur on top of and laterally from the lava/domes (Rosa et al. 2011).

The cryptodomes and partly extrusive cryptodomes, contrary to the lava/domes, consist of thick intervals of coherent facies and thin margins of hyaloclastite and autobreccia. The partly extrusive cryptodomes may have small aprons of redeposited hyaloclastite. The pyroclastic units display mainly fiamme, interpreted to have been pumice clasts, crystal fragments and sedimentary and dense volcanic clasts (Rosa et al. 2010a). The pyroclastic deposits can occur as thin units with limited lateral extent overlying the lava/domes, or as relatively thick units with several kilometres of extension, indicating that explosive eruptions produced a significant volume of felsic rocks.

The VSC also comprises well-defined beds of volcanogenic sandstones and breccias, locally 
showing graded bedding and load casts. These units occur laterally or above the volcanic centres and their bedded nature indicate that they were deposited from water-supported gravity currents (Rosa et al. 2011). The composition is consistent with a source from the clastic volcanic components of the lava/domes and pyroclastic units (Rosa et al. 2010a).

Some massive sulphide ore deposits occur on top of the felsic effusive units (e.g. Neves Corvo, Aljustrel, São Domingos and Lousal; Rosa et al. 2008, 2010a, b), and the mineralizing hydrothermal alteration stockworks are hosted and deeply rooted in these units. These spatial associations suggest that the ore-forming hydrothermal activity occurred at the late stages of effusive volcanic events, and that also a strong genetic relationship between the ore-forming processes and the volcanic activity exists. Within the volcanic centres, the stockworks were emplaced preferentially in the breccia zones (autoclastic and pyroclastic) due to their low permeability, which favoured the circulation of hydrothermal fluids.

\subsection{Geochemistry of Volcanic Rocks}

Volcanism of the Volcanic Sedimentary Complex (VSC) is mainly bimodal, with a predominance of felsic (dacitic to rhyolitic volcanites) over basic rocks (basalts and dolerites). Although subordinate on a regional scale, andesitic lavas also occur (Munhá 1983; Mitjavila et al. 1997; Díez-Montes et al. 1999).

Felsic rocks range from dacite to high-Si rhyolites and belong to a calc-alkaline series. Rhyolites (and Sierra Norte Batholith leucogranites) show similar REE patterns displaying moderate LREE enrichment, pronounced negative Eu anomalies, and relatively flat to slightly HREE enrichment (Munhá 1983; Díez-Montes and Bellido-Mulas 2008). Dacites (and tonalites) are enriched in $\mathrm{Al}_{2} \mathrm{O}_{3}, \mathrm{TiO}_{2}$, and $\mathrm{P}_{2} \mathrm{O}_{5}$ and display smaller negative $\mathrm{Eu}$-anomalies relative to most rhyolites (e.g., Munhá 1983). On primitive mantle-normalized spider plots for trace elements, all the intermediate-felsic rocks show similar patterns, with negative anomalies in $\mathrm{Nb}$, $\mathrm{Th}$ and $\mathrm{Ti}$ (Díez-Montes and Bellido-Mulas 2008). As a group, they define a low-Al TTG and high-HREE series (Arth et al. 1978), broadly equivalent to the FII dacite-rhyolite group of Lesher et al. (1986), Hart et al. (2004). These series are commonly related to massive sulphide deposits.

Dacites and rhyolites exhibit an enriched crustal signature based on the $\mathrm{Nd}$ and $\mathrm{Sr}$ isotopic systematics, consistent with derivation from an older crust (Mitjavila et al. 1997). The zircon inheritance provides direct evidence for older (Proterozoic to Ordovician) detrital components in their source rocks (Barrie et al. 2002; Rosa et al. 2009). The diversity of chemical and $\mathrm{Sr}-\mathrm{Nd}$ isotopic composition of rhyolites, dacites and minor andesites can mainly be explained either by differences in composition of the source rocks or by different degrees of partial melting of upper crust (e.g., Mitjavila et al. 1997). Andesites have been interpreted as formed due to contamination (mixing) between basaltic magmas and uppercrust material (Mitjavila et al. 1997). The geochemical characteristics of felsic magmatism suggest that they were generated by fractionation/partial melting of amphibolites at low pressures, involving plagioclase and pyroxene in the petrogenetic process without involvement of garnet, and with a significant contamination of crustal material (Díez-Montes and Bellido-Mulas 2008).

The geochemical similarities between the volcanic rocks of the VSC and the TTG plutonic rocks of the SNB (Schütz et al. 1987; Thiéblemont et al. 1998; Díez-Montes and Bellido-Mulas 2008; Díez-Montes et al. 2011), as well as the available U-Pb geochronology data (Barrie et al. 2002; Dunning et al. 2002; Valenzuela et al. 2011) suggest that the Volcano-Sedimentary Complex was approximately coeval and cogenetic with the TTG plutonic rocks of the Sierra Norte Batholith.

Based on geochemical characteristics of rocks and minerals, two main types of mafic rocks are distinguished: (1) tholeiitic lavas, which crop out across the whole IPB; and (2) alkaline lavas and 
dolerites which are similar to recent within-plate basalts, and restricted to the western and southern parts of the IPB. According to Munhá (1983) alkaline basalts are restricted to the upper part of the volcanic sequence, in the Portuguese sector, while in the Spanish sector there is no evidence of a temporal evolution from tholeiitic to alkaline basalts (e.g., Mitjavila et al. 1997).

The tholeiitic lavas show a wide range of geochemical characteristics, medium $\mathrm{La} / \mathrm{Nb}$ (1-2) and Y/Nb (2-7) compositions, similar to recent continental tholeiites, whereas higher ratios of $\mathrm{La} / \mathrm{Nb}(>2)$ and $\mathrm{Y} / \mathrm{Nb}(>6)$ have some affinities to arc-related basalts (Munhá 1983; Thiéblemont et al. 1998). Alkaline-affinity basalts show higher $\mathrm{TiO}_{2}, \mathrm{P}_{2} \mathrm{O}_{5}$, and LREE and lower $\mathrm{Y} / \mathrm{Nb}$ ratio. The lavas with andesitic compositions are spatially and temporally associated with tholeiitic basic lavas and fall into the field of normal calc-alkaline series rocks $\left(\mathrm{K}_{2} \mathrm{O}<2.5 \mathrm{wt}\right.$ \%; e.g. Munhá 1983).

Although closely associated, the felsic and mafic volcanic rocks originated and evolved independently. No lithological transitions occur, the volcanic centres are distinct, and available geochemical and isotopic data refute any relationship by pure fractional crystallization between basalts, andesites and felsic rocks (e.g., Munhá 1983; Mitjavila et al. 1997). The mafic rocks were formed due to partial melting of the asthenospheric mantle, whereas the felsic volcanism derived from crustal anatexis, possibly promoted by heat supplied by rising mafic magmas (Munhá 1983; Mitjavila et al. 1997; Thiéblemont et al. 1998), at low- to mediumpressures and steep geothermal gradients. This makes the IPB different from the massive sulphide-bearing volcanic arc-related series and settings (Leistel et al. 1998).

Petrogenetic modelling of trace elements of the various basalts precludes an evolution solely by fractional crystallization and the variable compositions can be explained by a single mixing model between E- and N-MORB and assimilation of crustal material (Mitjavila et al. 1997). However, the mixing model between $\mathrm{E}-$ and NMORB used to explain the origin of the most primitive basaltic rocks does not discriminate between the origin of both tholeiitic and alkaline affinities in the same magmatic context (Mitjavila et al. 1997). The existence of tholeiitic and alkaline rocks may be explained by different degrees of partial melting of a peridotitic mantle (Mitjavila et al. 1997), but according to Munhá (1983) at least two different mantle sources are required to explain the compositional differences.

Overall, the bimodal nature, with continental tholeiites and the alkaline character of some lavas, with only minor amounts of intermediate rocks, points to a consensual extensional tectonic setting for the genesis of VSC (e.g., Munhá 1983; Mitjavila et al. 1997; Thiéblemont et al. 1998; Rosa et al. 2006). However, there are different opinions regarding the regional significance of this extensional tectonic setting.

\subsection{Structural and Tectonic Evolution}

The IPB is interpreted to correspond to basins generated by the oblique collision of the South Portuguese Zone and the autochthonous Iberian terranes (north Gondwana), during the DevonianCarboniferous (Silva et al. 1990; Quesada 1991; Oliveira et al. 2004; Tornos et al. 2005). This transtensive tectonic regime triggered volcanism that formed the felsic and mafic volcanic rocks that occur in the IPB, and the geothermal gradients that permitted the hydrothermal activity responsible for the IPB massive sulphide deposits. The change to a transpressive regime was responsible for the Variscan deformation (Upper Devonian to Carboniferous) that disrupts the IPB stratigraphy, corresponding to a thinskinned foreland fold and thrust belt (Silva et al. 1990; Quesada 1998), confirmed by deep seismic reflection studies (Simancas et al. 2003). The IPB structure e.g. in the Central Domain of South Portuguese Zone (Fig. 9.1; Mantero et al. 2007), is characterized by northwest-southeast trending folds verging towards southwest (with axial plane cleavage steeply dipping to NE) and thrusts in the western part of the IPB, and east-west 
trending folds verging towards south (with cleavage dipping to $\mathrm{N}$ ) and thrusts in the central and eastern IPB.

Late- to post-Variscan faulting is expressed as oblique strike-slip faults. N-S to NNW-ESEstriking, dextral/extensional faults, conjugate NE-SW to ENE-WSW-striking, sinistral/extensional faults, such as the Messejana Fault (with $4 \mathrm{~km}$ of displacement and down-drop of the NW block), and additional E-W-striking, commonly sinistral faults (Ribeiro 1984; Schermerhorn et al. 1987; Oliveira and Araújo 1992; Liñán 1994; Quesada 1996, 1998; Leitão 1997) are the main features. $\mathrm{Cu}, \mathrm{Pb}$ and $\mathrm{Ba}$ mineralized quartz/ carbonate veins typically infill some of these faults, particularly the NE-SW to ENE-WSWstriking faults, and Mesozoic (?) microgabbro and lamprophyre dykes were later emplaced within the same fault set in the Portuguese part of IPB (Oliveira and Araújo 1992).

\subsection{Mineral Deposits}

\subsubsection{General}

The IPB contains about 90 volcanogenic massive sulphide (VHMS) deposits, estimated before erosion at over $1700 \mathrm{Mt}$ containing $14.6 \mathrm{Mt} \mathrm{Cu}$, 34.9 Mt Zn, 13.0 Mt Pb, 46,100 t Ag, 880 t Au and significant amounts of other metals, in particular Sn (Leistel et al. 1998). About $20 \%$ of the total amount has been mined and $10-15 \%$ was lost to erosion. The belt includes eight giant VHMS deposits, >100 Mt: Rio Tinto, Tharsis, Aznalcóllar-Los Frailes, Masa Valverde, SotielMigollas and La Zarza in Spain and Neves Corvo and Aljustrel in Portugal. Three of these are supergiants (>200 Mt): Río Tinto $(500 \mathrm{Mt})$, Neves Corvo (>300 Mt) and Aljustrel (>200 Mt). Additional world-class VHMS deposits ( $>30 \mathrm{Mt}$ ) are Concepción, La Romanera, Aguas Teñidas Este and Las Cruces in Spain, and Lousal and S. Domingos in Portugal. The average grade of all VHMS deposits in the IPB is $45 \% \mathrm{~S}, 40 \% \mathrm{Fe}$, $1.3 \% \mathrm{Cu}, 2.0 \% \mathrm{Zn}, 0.7 \% \mathrm{~Pb}, 26 \mathrm{~g} / \mathrm{t} \mathrm{Ag}$ and
$0.5 \mathrm{~g} / \mathrm{t} \mathrm{Au}$ (Carvalho et al. 1999). Hundreds of Mn occurrences and small deposits are also related to the felsic volcanism, the most significant being Solo Viejo in Spain (Carvalho et al. 1976, 1999; Barriga et al. 1997; Leistel et al. 1998; Tornos et al. 2000; Relvas et al. 2002, 2006a; Matos et al. 2006; Tornos 2006).

The massive sulphide deposits range in thickness from $1 \mathrm{~m}$ to tens of metres and up to a few kilometres in extension. Many of the major deposits display several clustered lenses $(2-7$ in the giant deposits). Furthermore, tectonic stacking significantly increased the thickness of massive ore bodies in some deposits. Despite thrusting, most of the massive sulphides ore piles are underlain by, or imbricated with large stockwork or stringer zones, made up of sulphide-bearing, mm-thick stringers to dm-thick veins (Carvalho 1979; Leistel et al. 1998).

Several classifications have been applied to these deposits. They are divided into stratiform polymetallic massive sulphide bodies, mostly pyritic (35-51 \% S or 66-96 \% pyrite equivalent), semi-massive to disseminated polymetallic pyrite bodies ("safrão"), with $<35 \% \mathrm{~S}$ and stockwork ores $(5-25 \% \mathrm{~S}$ or $10-25 \%$ pyrite equivalent) in the footwall, well developed in Rio Tinto, Aznalcóllar, La Zarza, Concepción, Aljustrel (Feitais) and Neves Corvo (Strauss et al. 1977; Carvalho et al. 1999). The IPB deposits are also included in the felsic-siliciclastic type of Barrie and Hannington (1999). Based on Large's (1992) metal content classification most of these VHMS deposits are $\mathrm{Zn}-\mathrm{Pb}-\mathrm{Cu}$ or $\mathrm{Zn}-\mathrm{Cu}-\mathrm{Pb}$ types (including the giant deposits), with a few $\mathrm{Cu}$ and $\mathrm{Cu}-\mathrm{Pb}$ types, and possibly still a few others belonging to the $\mathrm{Zn}-\mathrm{Pb}$ type (Tornos et al. 2000). The zones with high $\mathrm{Zn}-\mathrm{Pb}$ or $\mathrm{Cu}$ are currently the main mining targets.

Depending on their tectonic position, these VHMS deposits can be classified as autochthonous (rooted or proximal), transitional or allochthonous (redeposited or distal), with most deposits having stockwork included in the autochthonous and transitional sub-types, while some ore bodies in the Lousal, Sotiel and Tharsis deposits, without stockwork or hydrothermal 
alteration are considered as allochthonous (Carvalho 1979; Barriga et al. 1997; Carvalho et al. 1999).

Based on the dominant geologic setting, Tornos (2006) classified these deposits as:

(a) shale-related massive sulphide deposits, in which the massive sulphides are clustered in isolated VSC outcrops and in direct relationship to black shales volumetrically important in the VSC pile, either directly above the contact of the PQG and the VSC or above dacitic domes. These deposits are usually large, stratabound and pyrite rich, showing characteristic sedimentary features and sometimes displaying a typical sideritepyrite ore. These deposits, many of them dated as Strunian (Pereira et al. 2008; González 2005), are located in the southern IPB and include Las Cruces, AznalcóllarLos Frailes, Valverde, Sotiel-Migollas, Tharsis and Neves Corvo;

(b) felsic volcanic-hosted massive sulphide deposits, with minor or absent shale, with the stockwork rooted in felsic volcanic domes, many of which of early Tournaisian age, either hosted in the dome pumice- and glass-rich volcaniclastic rocks or in the dome carapace. They occur in the northern IPB and are exemplified by Río Tinto (Filón Norte), Concepción, Aguas Teñidas Este, La Zarza and Aljustrel.

$\mathrm{Re}-\mathrm{Os}$ and $\mathrm{Rb}-\mathrm{Sr}$ isotopic ages for sulphide and tin ores from Neves Corvo indicate formation ages of $358 \pm 29$ and $347 \pm 25$ Ma respectively (Munhá et al. 2005; Relvas et al. 2001). Based on Re-Os isotopes for the Tharsis and Río Tinto ores the obtained formation ages, also with considerable errors, were $353 \pm 44$ and $346 \pm 26$ Ma respectively (Mathur et al. 1999). As stated above, a late Strunian palynological age was obtained for the shales enclosing the massive sulphide ore in Neves Corvo, Lousal, Caveira, Montinho, Aznalcóllar and Tharsis.

\subsubsection{Mineralogy}

The four major minerals in massive ore are dominant fine- to medium-grained pyrite (commonly recrystallized), sphalerite, chalcopyrite and galena (also cassiterite at Neves Corvo). These minerals are also present in stockwork ore together with a quartz-chlorite-sericite-carbonate assemblage, but in different proportions. Many of the deposits exhibit common clastic textures, mostly sedimentary, but in places of tectonic origin, involving pyrite and other minerals within the massive sulphide ore pile. Accessory minerals in both ore types are tetrahedrite-tennantite, bournonite, arsenopyrite and pyrrhotite. The numerous trace minerals include magnetite (can be accessory) and electrum (Yamamoto et al. 1993; Gaspar 1996; Leistel et al. 1998; Carvalho et al. 1999). Not only sphalerite with chalcopyrite disease, but also Bi and Co sulphosalts and sulphides occur in the stockwork ore and at the base of the massive sulphide interacting with it (Marcoux et al. 1996). Tin sulphides (stannite, kesterite, mawsonite and stannoidite) occur in both massive and stockwork ores as trace minerals but are common in Neves Corvo, especially in $\mathrm{Sn}$ and $\mathrm{Cu}-\mathrm{Sn}$ ores (Gaspar and Pinto 1991; Gaspar 2002).

\subsubsection{Geochemistry}

The classical VHMS zonation is present in several VHMS deposits in IPB, with $\mathrm{Cu}$-rich stockwork and base of massive ore, and $\mathrm{Zn}-\mathrm{Pb}$ massive ore above and extending laterally. Au is more enriched in stockwork and distal parts of the orebodies, whereas Ag is mostly associated with massive $\mathrm{Zn}-\mathrm{Pb}$ ore (Leistel et al. 1998; Carvalho et al. 1999). Common chalcopyrite disease textures in sphalerite and $\mathrm{Bi}, \mathrm{Co}, \mathrm{Te}, \mathrm{Se}$ and $\mathrm{Cu}$ minerals in both stockwork and basal part of the massive ore interacting with it apparently reflect late-stage copper enrichment from hightemperature $\mathrm{Cu}$-bearing fluids (Marcoux et al. 1996). 
S-isotope values of -35 to +12 per mil have been reported for pyrite and other sulphide minerals, ranging from more negative values in massive ore to more positive in stockwork ore, and indicating a predominance of reduced seawater sulphur (as do values up to $28 \%$ in barite), but with involvement of bacteriogenic sulphur particularly in samples with more negative values (Mitsuno et al. 1988; Barriga 1990; Yamamoto et al. 1993; Velasco et al. 1998; Inverno et al. 2008; Tornos et al. 2008). $\delta^{18} \mathrm{O}$ and $\delta \mathrm{D}$ values for the hydrothermal fluids responsible for the ore formation are 0 to +7 per mil and -10 to +15 per mil, respectively, indicating seawater derivation with minor contribution from magmatic or metamorphic reservoirs (Barriga and Kerrich 1984; Munhá et al. 1986b; Barriga et al. 1997; Inverno et al. 2008). The $\delta^{13} \mathrm{C}$ values of carbonates from massive and stockwork ores $(-14.3$ to $-5.0 \%$ ) indicate a $\delta^{13} \mathrm{C}_{\text {fluid }}$ of -15.9 to -6.6 per mil for the Aljustrel and Tharsis deposits. Coupled with O-isotope values from these carbonates, this suggests that carbonate was derived from mixing of seawater with a hot hydrothermal fluid and/or methane from degradation of organic matter, with the last to explain the lowest values (Inverno et al. 2008; Tornos et al. 2008).

The lead isotope composition (Marcoux 1998) is very similar for massive ores, the stockwork ores and for the volcanic host rocks throughout the belt, indicating that $\mathrm{Pb}$ in the ores and volcanic rocks was derived from the same continental crust. Only Neves Corvo displays a highly radiogenic $\left({ }^{208} \mathrm{~Pb} /{ }^{204} \mathrm{~Pb}>18.4\right.$ in cassiterite) stanniferous ore, implying a more complex oreforming process with metals derived from the basement, volcanic rocks or a magmatic source of lead (Barriga et al. 1997; Carvalho et al. 1999; Tornos et al. 2000; Relvas et al. 2001). Reported ${ }^{87} \mathrm{Sr} /{ }^{86} \mathrm{Sr}$ ratios in barite from Feitais (Aljustrel) hanging wall rocks and from the massive ore (0.708836-0.709063), from hydrothermal minerals at Tharsis (0.707301$0.722085)$, and from various Neves Corvo ore types (0.710881-0.713556), are all more radiogenic than late Strunian seawater (0.70800.7085 ) and than felsic volcanic rocks in the IPB in Spain (Mitjavila et al. 1997) This suggests that ore-forming fluids in Feitais resulted from mixing of seawater with a crustal fluid (Inverno et al. 2008), only the latter fluid type would explain the high radiogenic values from Neves Corvo, particularly the tin ores (Relvas et al. 2001). The two sources explain both the low and the high values in Tharsis, the latter suggesting equilibration with either the PQG or an unknown underlying basement (Tornos and Spiro 1999; Tornos 2006).

\subsubsection{Hydrothermal Alteration}

A low-temperature regional seawater dominant alteration in the basalts and rhyolites, converted into "spilites" and "quartz keratophyres", respectively (Munhá 1990), was overprinted by higher temperature ore-zone hydrothermal alteration, both in the foot- and hanging wall, predating regional metamorphism. The footwall alteration consists of an internal stockwork zone with chlorite-quartz-sulphides (-carbonates), surrounded by an intermediate, peripheral stockwork zone with sericite-quartz-sulphides (-carbonates). In some deposits (e.g. Gavião, Aljustrel) these are surrounded by a distal, ultraperipheral stockwork zone with quartzsericite-Na-sericite-chlorite-sulphide, with an overall removal of alkalis from the internal zone, fixing of $\mathrm{K}(+\mathrm{Ba})$ in the intermediate zone, and addition of $\mathrm{Na}$ in the outer zone (Barriga et al. 1997; Tornos et al. 1998, 2000; Carvalho et al 1999; Relvas et al. 2011). Pyrophyllite, indicative of advanced argillic alteration in the internal zone, may be present in a few deposits (e.g., Lagoa Salgada) (Relvas et al. 1994; Oliveira et al. 1998; Matos et al. 2000; de Oliveira et al. 2011). When hosted in shales, the hydrothermal alteration related to stockworks is restricted to the chloritic type (Tornos et al. 1998, 2000).

Hanging wall alteration of many VHMS deposits in the IPB affects volcanic rocks, when present, cherts and jaspers, and pelitic sedimentary rocks. Volcanic rocks are altered to sericiticor chloritic-dominated pyrite-bearing rocks while jaspers turn into cherts above the ore zone due to hematite reduction to magnetite and formation of chlorite+carbonate+pyrite and Mn silicates, 
carbonates and oxides. As to pelitic sedimentary rocks, they commonly but not always, come to be veined with significant chlorite (Mn-rich), sericite, carbonate, barite and sulphide (Barriga and Fyfe 1988; Carvalho et al. 1999; Tornos et al. 2000; Inverno et al. 2008).

\subsubsection{Metallogenesis}

It is generally accepted that the IPB massive sulphides precipitated at or near the sea floor, from a dominant hydrothermal seawater fluid, as substantiated by $\mathrm{O}-$ and $\mathrm{H}$-isotope data (Munhá et al. 1986b). However, it is disputed whether subseafloor replacement occurred. Tornos et al. (2000) suggested the existence of deposits formed on the sea floor with minor footwall replacement (e.g., Río Tinto, Planes-San Antonio), deposits formed by shallow subseafloor replacement of black muds (e.g., Aznalcóllar), and deposition by replacement ( $>50 \mathrm{~m}$ depth?) of reactive volcanic rocks related to stockworks, as is the case in many deposits in the northern IPB. Sáez et al. (1999) went further and proposed that most IPB massive sulphide deposits formed by subseafloor replacement of black muds. Barriga and Fyfe (1988), Barriga (1990) proposed that Aljustrel massive sulphide deposits, particularly Feitais, formed by shallow subseafloor replacement of volcanic and sedimentary rocks beneath a jasper cap that inhibited oxidation and dispersion of sulphides.

Currently, there are two models for the origin of VHMS mineralization in the IPB. In one, a magmatic fluid contribution to the hydrothermal dominant seawater depositional fluid has been suggested. High grade $\mathrm{Au}$ ores at La Zarza (Strauss and Beck 1990), pyrophyllite at Lagoa Salgada stockwork, suggesting advanced argillic alteration akin to high sulphidation deposits, and $\mathrm{Sn}$ ores and $\mathrm{Cu}$-rich complex ores at Neves Corvo, where zone refining occurs and $\mathrm{Bi}-\mathrm{Co}-\mathrm{Te}-\mathrm{Se}-\mathrm{Cu}$ minerals are present in stockwork and base of massive ore, are all suggestive of a magmatichydrothermal contribution at least in a few of the VHMS deposits in IPB (Relvas et al. 1994; Carvalho et al. 1999). O-, H- and C-isotope data from Neves Corvo are consistent, for the highest temperature fluids, with the involvement of a nonseawater fluid, possibly magmatic-hydrothermal fluids exsolved from a hypothetical granitic pluton emplaced at depth (Relvas et al. 2006b). However, despite the fact that melt inclusions in quartz phenocrysts in the IPB felsic volcanic rocks suggest possible Sn-rich granites at depth (Huston et al. 2011), the felsic (dacitic to rhyolitic) subvolcanic sills occurring in several areas intruded after the formation of the VHMS deposits, contradicting Boulter's (1996) hypothesis that the intrusions triggered massive sulphide formation. Additionally, basaltic subvolcanic sills predate massive sulphides in Rio Tinto and Tharsis (Tornos et al. 1998, 2000), although in Aznalcóllar they occur beneath the massive sulphide deposits and therefore a link was suggested between mafic volcanism and VHMS deposits as possible in Aznalcóllar (Almodóvar et al. 1998; Sáez et al. 1999). In fact, in other VHMS belts there are massive sulphide deposits interpreted as formed by magmatic-hydrothermal fluids derived from subvolcanic felsic igneous complexes accompanied by mafic-ultramafic rocks (Galley 2003; Díez-Montes and Bellido-Mulas 2008). An alternative to the magmatic contribution to the hydrothermal seawater fluid could be metamorphic or crustal fluids (Sánchez-España et al. 2003; Moura 2005).

The second model is mainly based on the isotope geochemistry and geology of the deposits of the southern part of the belt. Here, the radiogenic isotope values and the lack of evidence of magmatic-hydrothermal fluids led Tornos (2006) to propose that the fluids were derived from the PQG or the underlying basement during the extension and high heat flow, which promoted faster diagenesis and dewatering of the siliciclastic sediments. The model implies the separation of fluids with intermediate salinities, rich in metals, but carrying little reduced sulphur, which were rising through the crust until they mixed with reduced seawater (Tornos and Heinrich 2008).

Additionally, deposition of the massive sulphides in a brine pool and not in a Kuroko-type mound has been proposed for several VHMS 
deposits in the IPB, mostly from the southern branch, in part due to the morphology of the orebodies and to the presence of high-saline oreforming fluids (Tornos et al. 1998; Solomon et al. 2002, 2004). This has been suggested for San Miguel, San Telmo, Aguas Teñidas and Río Tinto (Sánchez-España et al. 2003), Masa Valverde (Toscano et al. 1997), Tharsis (Tornos and Spiro 1999; Tornos et al. 2008), Aznalcóllar and Los Frailes (Almodóvar et al. 1998) and FeitaisAljustrel (Inverno et al. 2008).

\section{References}

Almodóvar, G.R., Saéz, R., Pons, J.M., Maestre, A., Toscano, M., Pascual, E. 1998. Geology and genesis of the Aznalcóllar massive sulphide deposits, Iberian Pyrite Belt, Spain. Mineralium Deposita, 33: 111-136.

Arth, J.G., Barker, F., Peterman, Z.E., Friedman, I. 1978. Geochemistry of the gabbro-diorite-tonalite-trondhjemite suite of southwest Finland and its implications for the origin of tonalitic and trondhjemitic magmas. Journal of Petrology, 19 (2): 289-316.

Barrie, C.T., Amelin, Y., Pascual, E. 2002. U-Pb geochronology of VMS mineralisation in the Iberian Pyrite Belt. Mineralium Deposita, 37: 684-703.

Barrie, C.T., Hannington, M.D., 1999. Introduction: Classification of VMS deposits based on host rock composition. Reviews in Economic Geology, 8: 1-12.

Barriga, F.J.A.S. 1990. Metallogenesis in the Iberian Pyrite Belt. In: Dallmeyer, R.D., Martínez García, E., (eds.). Pre-Mesozoic Geology of Iberia. Berlin, Springer-Verlag, p. 369-379.

Barriga, F.J.A.S., Fyfe, W.S. 1988. Giant pyritic basemetal deposits: The example of Feitais (Aljustrel, Portugal). Chemical Geology, 69: 331-343.

Barriga, F.J.A.S., Kerrich, R. 1984. Extreme ${ }^{18} \mathrm{O}$-enriched volcanics and ${ }^{18} \mathrm{O}$-evolved marine water, Aljustrel, Iberian Pyrite Belt: Transition from high to low Rayleigh number convective regimes. Geochimica et Cosmochimica Acta, 48: 1021-1031.

Barriga, F.J.A.S., Carvalho, D., Ribeiro, A. 1997. Introduction to the Iberian Pyrite Belt. In: Barriga, F.J.A.S., Carvalho, D. (eds.). Geology and VMS deposits of the Iberian Pyrite Belt. Society of Economic Geologists Neves Corvo Field Conference, Guidebook Series, 27: 1-20.

Boogaard, M. V. 1963. Conodonts of upper Devonian and lower Carboniferous age from southern Portugal. Geol. Mijnbouw, 42 (8): 248-259.

Boogaard, M. V., Schermerhorn, L.J.G. 1980. Conodont faunas from Portugal and southwestern Spain. Part 4A Famennian conodont fauna near Nerva (Río Tinto). Scrip. Geol., 56: 1-14.
Boogaard, M. V., Schermerhorn, L.J.G. 1981. Conodont faunas from Portugal and southwestern Spain. Part 6A lower Famennian conodont fauna at Monte Forno da Cal (South Portugal). Scrip. Geol., 63, 1-16.

Boulter, C.A. 1993. High-level peperitic sills at Río Tinto, Spain: Implications for stratigraphy and mineralization. Transactions Inst. Mining Metallurgy (Section B: Applied Earth Science), 10: B30-B38.

Boulter, C.A. 1996. Extensional tectonics and magmatism as drivers of convection leading to Iberian massive sulphide deposits? Journal of the Geological Society, 153: 181-184.

Braid, J.A, Murphy, J.B., Quesada, C., Mortensen, J. 2011. Tectonic escape of a crustal fragment during the closure of the Rheic Ocean: U-Pb detrital zircon data from the Late Paleozoic Pulo do Lobo and South Portuguese zones, southern Iberia. Journal of the Geologica Society, 168: 383-392.

Carvalho, D. 1979. Geologia, metalogenia e metodologia da investigação de sulfuretos polimetálicos do Sul de Portugal. Comunicações Serviços Geológicos Portugal, 65: 169-191 (in Portuguese; abstract in English).

Carvalho, D., Conde, L., Enrile, J.H., Oliveira, V., Schermerhorn, L.J.G.S. 1976. Livro-guia das excursões geológicas na Faixa Piritosa Ibérica, na III Reunião do Sudoeste no Maciço Hespérico da Península Ibérica. Comunicações Serviços Geológicos Portugal, 60: 271-315 (in Portuguese).

Carvalho, D., Barriga, F.J.A.S., Munhá, J. 1999. Bimodal siliciclastic systems: the case of the Iberian Pyrite Belt. Reviews in Economic Geology, 8: 375-408.

De La Rosa, J.D. 1992. Petrología de las rocas básicas y granitoides del Batolito de la Sierra Norte de Sevilla. Zona Surportuguesa. Macizo Ibérico. Unpublished Doctoral Thesis, Univ. of Sevilla, 312 pp.

de Oliveira, D.P.S., Matos, J.X., Rosa, C.J.P., Rosa, D.R. N., Figueiredo, M.O., Silva, T.P., Guimarães, F., Carvalho, J.R.S., Pinto, A.M.M., Relvas, J.R.M.S., Reiser, F.K.M. 2011. The Lagoa Salgada orebody, Iberian Pyrite Belt, Portugal: Geology, distribution, mineralogy and geochemistry of Indium. Economic Geology, 106: 1111-1128.

Díez-Montes, A., Bellido-Mulas, F. 2008. Magmatismo TTG y Al-K en la Zona Surportuguesa. Relaciones entre plutonismo y vulcanismo. VII Congreso Geológico de España. Las Palmas de Gran Canaria (España). Geo-Temas, 10: 1449-1452.

Díez-Montes, A., Matas, J., Leyva, F., Martín Parra, L.M. 1999. Mapa geológico a escala 1:50.000, Hoja 939-III (Minas del Castillo de las Guardas). In: Donaire, M. and Almarza, J. (eds.). Investigación geológica y cartografía básica en la Faja Pirítica y áreas aledañas. Junta de Andalucía \& Instituto Geológico y Minero de España. Available on line: http://www.juntadeandalucia. es/innovacioncienciayempresa/sigma/paginas/productos/ fpi.jsp.

Díez-Montes, A., Bellido, F., Sánchez García, T. 2011. TTG and Al-K magmatisms in the South Portuguese Zone. Relations between plutonism and volcanism. 
Seventh Hutton Symposium on Granites and Related Rocks. Ávila (Spain). Abstract Book, p. 47.

Donaire, T., Sáez, R., Pascual, E. 2002. Rhyolitic globular peperites from the Aznalcóllar mining district (Iberian Pyrite Belt, Spain): physical and chemical controls. Journal of Volcanology and Geothermal Research, 114: 119-128.

Dunning, G.R., Díez-Montes, A., Matas, J., Martín Parra, L.M., Almarza, J., Donaire, M. 2002. Geocronología $\mathrm{U} / \mathrm{Pb}$ del volcanismo ácido y granitoides de la Faja Pirítica Ibérica (Zona Surportuguesa). Geogaceta: 32: 127-130

Galley, A.G. 2003. Composite synvolcanic intrusions associated with Precambrian VMS-related hydrothermal systems. Mineralium Deposita, 38: 443-473.

Gaspar, O.C., 1996. Microscopia e petrologia de minérios aplicadas à génese, exploração e mineralurgia dos sulfuretos maciços dos jazigos de Aljustrel e NevesCorvo. Estudos, Notas e Trabalhos, Instituto Geológico e Mineiro, 38: 3-195 (in Portuguese; extended abstract in English).

Gaspar, O.C. 2002. Mineralogy and sulfide mineral chemistry of the Neves-Corvo ores, Portugal: Insight into their genesis. Canadian Mineralogist, 40: 611636.

Gaspar, O., Pinto, A. 1991. The ore textures of the NevesCorvo volcanogenic massive sulphides and their implications for ore beneficiation. Mineralogical Magazine, 55: 417-422.

Gladney et al., 2014 (in press). The Gil Marquez pluton, Southern Iberia: Magmatism during continental amalgamation of Pangea. International Journal of Earth Sciences.

González, F. 2005. Las pizarras negras del límite Devónico/Carbonífero de la Faja Pirítica Ibérica (SO de España). Estudio bioestratigráfico e implicaciones sobre la paleogeografía de la cuenca y el origen de las mineralizaciones de sulfuros. Ph.D. Thesis, Huelva, 200 p.

González, F., Moreno, C., Sáez, R., Clayton, J. 2002. Ore genesis age of the Tharsis Mining District, Iberian Pyrite Belt: a palynological approach. Journal of the Geological Society, 159, 229-232.

Halsall, C.E. 1989. The relationship between intrusive magmatism, volcanism and massive sulphide mineralisation at Rio Tinto, Spain. Unpublished Doctoral Thesis, Univ. of London, 298 pp.

Hart, T.R., Gibson, H.L., Lesher, C.M. 2004. Trace element geochemistry and petrogenesis of felsic volcanic rocks associated with volcanogenic massive $\mathrm{Cu}-\mathrm{Zn}-\mathrm{Pb}$ sulfide deposits. Economic Geology, 99: 1003-1013.

Huston, D.L., Relvas, J.M.R.S., Gemmell, J.B., Drieberg, S. 2011. The role of granites in volcanic-hosted oreforming systems: an assessment of magmatic-hydrothermal contributions. Mineralium Deposita, 46: 473-507.

IGME. 1982. Síntesis Geológica de la Faja Pirítica del SO de España. IGME, Madrid. 106 pp.
Inverno, C.M.C., Solomon, M., Barton, M.D., Foden, J. 2008. The Cu-stockwork and massive sulfide ore of the Feitais volcanic-hosted massive sulfifide deposit, Iberian Pyrite Belt, Portugal: A mineralogical, fluid inclusion, and isotopic investigation. Economic Geology, 103: 241-267.

Jorge, R., Fernandes, P., Pereira, Z., Oliveira, J.T. 2007. A late Famennian age storm-dominated succession at Berrocal, Iberian Pyrite Belt-Spain. In: Z. Pereira, J, T., Oliveira, R. Wicander (eds.), CIMP Lisbon 07Joint Meeting of Spores /Pollen and Acritarch Subcommissions. Abstracts, 83-87.

Jorge R.C.G.S, Fernandes, J.P., Rodrigues, B., Pereira Z., Oliveira J.T. 2012. Geochemistry and provenance of the Carboniferous Baixo Alentejo Flysch Group, South Portuguese Zone. Sedimentary Geology, (2013), http://dx.doi.org/10.1016/j.sedgeo.2012.12. 005.

Junta de Andalucía, 1999. Project: Investigación geológica y cartografía básica en la Faja Pirítica y áreas aledañas. Junta de Andalucía \& Instituto Geológico y Minero de España. Available on line: http://www. juntadeandalucia.es/innovacioncienciayempresa/ sigma/paginas/productos/fpi.jsp.

Large, R.R. 1992. Australian volcanic-hosted massive sulfide deposits: Features, styles, and genetic models. Economic Geology, 87: 471-510.

Laznicka, P. 1999. Quantitative relationships among giant deposits of metals. Economic Geology, 94: 455-473.

Leca, X., Ribeiro, A., Oliveira, J.T., Silva, J.B., Albouy, L., Carvalho, D., Merino, F., 1983. Cadre Géologique des Mineralisations de Neves Corvo (Baixo Alentejo, Portugal). Lithostratigraphie, Paléologéographie et Tectonique. Mémoire Bureau de Recherches Géologiques et Minières, 121, $80 \mathrm{pp}$.

Leistel, J.M., Marcoux, E., Thiéblemont, D., Quesada, C., Sánchez, A., Almodóvar, G.R., Pascual, E., Sáez, R. 1998. The volcanic-hosted massive sulphide deposits of the Iberian Pyrite Belt. Mineralium Deposita, 33: 2-30.

Leitão, J. 1997. Geology of the Aljustrel massive sulfide deposits. Society of Economic Geologists Field Trip Guidebook Series, 27: 82-97.

Lesher, C.M., Goodwin, A.M., Campbell, I.H., Gorton, M.P. 1986. Trace-element geochemistry of ore-associated and barren, felsic metavolcanic rocks in the Superior province, Canada. Canadian Journal of Earth Sciences, 23: 222-237.

Liñán, C. 1994. Mapa Geológico de la Península Ibérica, Baleares y Canarias, escala 1:1,000,000: Madrid, Instituto Tecnológico Geominero de España.

López, M.J., , Moreno, C., González, F., Dino, R., Antoniolli, L. 2004. Palinostratigrafía del Grupo Pizarroso-Cuartzítico del Sector más oriental de la Faja Pirítica Ibérica, SO de España. Revista Española de Micropaleontología, 36 (2): 279-304.

Mantero, E.M., García Navarro, E., Alonso-Chaves, F.M., Martín Parra. L.M., Matas, J., Azor, J. 2007. La Zona Sudportuguesa: propuesta para la división de un 
bloque continental en dominios. Geogaceta, 43: 27-30.

Marcoux, E. 1998. Lead isotope systematics of the giant massive sulfide deposits in the Iberian Pyrite Belt. Mineralium Deposita, 33: 45-58.

Marcoux, E., Moëlo, Y., Leistel, J.M. 1996. Bismuth and cobalt minerals as indicators of stringer zones to massive sulphide deposits, Iberian Pyrite Belt. Mineralium Deposita, 31: 1-26.

Martí Molist, J., Mitjavila de Balanzó, J., Soriano Clemente, C., Viladevall Solé, M. 1994. Proyecto de investigación Fundació Bosch i Gimpera-ITGE sobre la reconstrucción paleogeográfica y volcanológica de la Faja Pirítica del SW de España. IGME, Unpublished open-file report, code: 25072, $51 \mathrm{p}$.

Mathur, R., Ruiz, J., Tornos, F. 1999. Ages and sources of the ore at Tharsis and Rio Tinto, Iberian Pyrite Belt, from Re-Os isotopes. Mineralium Deposita, 34: 790-793.

Matos, J.X., Pereira, Z., Oliveira, V., Oliveira, J.T. 2006. The geological setting of the São Domingos pyrite orebody, Iberian Pyrite Belt. VII Congresso Nacional Geologia, Estremoz, Univ. Évora, Portugal, 283-286.

Matos, J.X., Barriga, F.J.A.S., Oliveira, V.M.J., Relvas, J. M.R.S., Conceição, P. 2000. The structure and hydrothermal alteration of the Lagoa Salgada orebody (Iberian Pyrite Belt - Sado Tertiary Basin). Volcanic Environments and Massive Sulfide Deposits - SEG/CODES International Conference Abstracts Volume-., Tasmania, Australia, 119-121.

Matos, J., Pereira, Z., Rosa, C., Rosa, D. N, Oliveira, J. T., Relvas, J., 2011. A key time frame for VMS deposit exploration in the Iberian Pyrite belt. $S G A$ 2011, $11^{\text {th }}$ Biennial Meeting, Antofagasta, Chile, 790-792.

Mitjavila, J., Martí, J., Soriano, C. 1997. Magmatic evolution and tectonic setting of Iberian Pyrite Belt volcanism. Journal of Petrology, 38: 727-755.

Mitsuno, C., Nakamura, T., Kanehira, K., Sugita, M., Kase, K., Thadeu, D., Carvalho, D., Arribas, A. 1988. Geological studies of the "Iberian Pyrite Belt"- with special reference to its genetic correlation of the Yanahara ore deposit and others in the inner zone of south-west Japan.. University Okayma, Japan, 300 p.

Moreno, C., Sáez, R., 1990. Sedimentación marina somera en el Devónico del Anticlinorio de Puebla de Guzman, Faja Pirítica Ibérica. Geogaceta, 8: 62-65.

Moreno, C., Sierra, S., Sáez, R., 1995. Mega-debris flows en el transito Devónico-Carbonífero de la Faja Piritica Ibérica. Geogaceta, 17: 9-11.

Moura, A. 2005. Fluids from the Neves Corvo massive sulphide ores, Iberian Pyrite Belt, Portugal. Chemical Geology, 223 (1-3), 153-169.

Munhá, J. 1983. Hercynian magmatism in the Iberian Pyrite Belt. In: Sousa, M.J.L., Oliveira, J.T. (eds.). The Carboniferous of Portugal. Memória Serviços Geológicos Portugal, 29: 39-81.

Munhá, J. 1990. Metamorphic evolution o the South Portuguese/ Pulo do Lobo Zone. In: Dallmeyer, R.D.,
Martínez García, E. (eds.). Pre-Mesozoic Geology of Iberia. Berlin, Springer-Verlag, p. 363-368.

Munhá, J., Oliveira, J.T., Ribeiro, A., Quesada, C., Kerrich, R. 1986a. Beja-Acebuches Ophiolite and geodynamic significance. Maleo, 2 (13): 31.

Munhá, J., Barriga, F.J.A.S., Kerrich, R. 1986b. High ${ }^{18} \mathrm{O}$ ore-forming fluids in volcanic-hosted base metal massive sulfide deposits: Geologic, ${ }^{18} \mathrm{O} /{ }^{16} \mathrm{O}$, and $\mathrm{D} / \mathrm{H}$ evidence from the Iberian Pyrite Belt, Crandon, Wisconsin, and Blue Hill, Maine. Economic Geology, 81: 530-552.

Munhá, J., Relvas, J.M.R.S., Barriga, F.J.A.S., Conceição, P., Jorge, R.C.G.S., Mathur, R., Ruiz, J., Tassinari, C.C.G. 2005. Os isotopes systematics in the Iberian pyrite belt. In: Mao, J., Bierlein, F.P., (eds.). Mineral deposit research: Meeting the global challenge, v. 1, Proceedings of the 8th Biennial SGA Meeting, Beijing, China, August 2005: Berlin, Germany, Springer-Verlag, p.: 663-666.

Nesbitt, R.W., Pascual, E., Fenning, C.M., Toscano, M., Sáez, R., Almodóvar, R.G. 1999. U-Pb dating of stockwork zircons from the eastern Iberian Pyrite Belt. Journal of the Geological Society London, 156: 7-10.

Oliveira, J. T. 1983. The marine Carboniferous of South Portugal: a stratigraphic and sedimentologic approach. In: Sousa, M., Oliveira, J.T. (eds.). The Carboniferous of Portugal. Memória dos Serviços Geológicos de Portugal, 29: 3-37.

Oliveira, J.T. 1990. Stratigraphy and syn-sedimentary tectonism in the South Portuguese Zone. In: Dallmeyer, R.D., Martínez García, E. (eds.). Pre-Mesozoic Geology of Iberia. Springer, Berlin, 334-347.

Oliveira, J.T., Araújo, A. 1992. Paleozóico-Tectónica tardi e pós-Varisca, in: Oliveira, J.T. (coord.), Notícia Explicativa da Folha 8, Carta Geológica de Portugal, escala 1:200,000: Lisboa, Serviços Geológicos de Portugal, p. 49-50 (in Portuguese).

Oliveira, J. T., Quesada, C. 1998. A comparison of stratigraphy, structure and paleogeography of the South Portuguese Zone and Southwest England, European Variscides. Annual Conference of the Ussher Society, Geoscience in South-west England, 141-150.

Oliveira, J.T., Horn, M., Paproth, E. 1979. Preliminary note on the stratigraphy of the Baixo Alentejo Flysch Group, Carboniferous of Southern Portugal and on the paleogeographic development, compared to corresponding units in Northwestern Germany. Comunicações Serviços Geológicos Portugal, 65: 151-168.

Oliveira, J. T., Carvalho, P., Pereira, Z., Pacheco, N., Korn, D. 2004. Stratigraphy of the tectonically imbricated lithological succession of the Neves-Corvo mine region, Iberian Pyrite belt. Implications for the regional basin dynamics. Mineralium Deposita, 34: 422-436.

Oliveira, J.T., Rosa, C.J.P., Rosa, D.R.N., Pereira, Z., Matos, J.X., Inverno, C.M.C., Andersen, T. 2013. Geology of the Neves-Corvo antiform, Iberian Pyrite Belt, Portugal: new insights from physical 
volcanology, palynostratigraphy and isotope geochronology studies. Mineralium Deposita, 48:749-766.

Oliveira, V., Matos, J.X., Bengala, M., Silva, N., Sousa, P. e Torres, L. 1998. Geology and geophysics as successful tools in the discovery of the Lagoa Salgada orebody (Sado Tertiary Basin - Iberian Pyrite Belt), Grândola, Portugal. Mineralium Deposita, 33: 170-187.

Pereira, M.F., Chichorro, M., Johnston, S.T., GutiérrezAlonso, G., Silva, J.B., Linnemann, U., Hofmann, M., Drost, K., 2012a. The missing Rheic Ocean magmatic arcs: provenance analysis of Late Paleozoic sedimentary clastic rocks of SW Iberia. Gondwana Research, 22 (3-4): 882-891.

Pereira, Z., Sáez, R., Pons, J., Oliveira, J., Moreno, C. 1996. Edad devónica (Struniense) de las mineralizaciones de Aznalcóllar, Faja Pirítica Ibérica, en base a palinología. Geogaceta, 20 (7): 1609-1612.

Pereira, Z., Fernandes, P., Oliveira, J. T., 2006. Palinostratigrafia do Domínio do Pulo do Lobo, Zona Sul Portuguesa. Comunicações Geológicas, INETI, 93: 23-38.

Pereira, Z., Matos, J., Fernandes, P., Oliveira, J.T. 2007. Devonian and Carboniferous palynostratigraphy of the South Portuguese Zone, Portugal - An overview. Comunicações Geológicas, 94: 53-79.

Pereira, Z., Matos, J., Fernandes, P. Oliveira J.T. 2008. Palynostratigraphy and Systematic Palynology of the Devonian and Carboniferous Successions of the South Portuguese Zone, Portugal. Memória No 34 do INETI, $1-176$.

Pereira, Z., Matos, J., Fernandes, P., Oliveira, J.T. 2009. A new Lower Givetian age Miospores of the Phyllite Quartzite Group (S. Francisco da Serra Anticline, Iberian Pyrite Belt, Portugal). In: Abstracts CIMPFARO'09. Fernandes, P., Pereira, Z., Oliveira, J.T., Clayton, C \& Wicander, R. (eds.), p. 75-78.

Pereira, Z., Matos, J., Rosa, C., Oliveira, J.T. 2012b. Palynostratigraphic importance of the Strunian in the Iberian Pyrite Belt. Joint Meeting of the 45th Annual Meeting of American Association Stratigraphic Palynology (AASP) - The Palynological Society and Meeting of Internacional Commission of Paleozoic Microflora (Cimp), Lexington, KY, USA, Abstract Book, 42-43.

Quesada, C. 1991. Geological constraints on the Paleozoic tectonic evolution of tectonostratigraphic terranes in the Iberian Massif. Tectonophysics, 185: 225-245.

Quesada, C. 1996. Estructura del sector español de la Faja Pirítica: implicaciones para la exploración de yacimientos. Boletín Geológico y Minero, 107 (3-4): 265-278.

Quesada, C. 1998. A reappraisal of the structure of the Spanish segment of the Iberian Pyrite Belt. Mineralium Deposita, 33: 31-44.

Quesada, C., Fonseca, P. E., Munhá, J., Oliveira, J.T., Ribeiro, A. 1994. The Beja-Acebuches Ophiolite (Southern Iberia Variscan Fold Belt): Geological characterization and significance. Boletín Geológico y Minero, 105: 3-49.
Relvas, J.M.R.S. 2000. Geology and metallogenesis at the Neves Corvo deposit, Portugal. Ph.D. Dissertation, University of Lisbon, 319 p.

Relvas, J.M.R.S., Barriga, F.J.A.S., Bernardino, F.B.C.P., Oliveira, V.M.S., Matos, J.X. 1994. Ore zone hydrothermal alteration in drill hole IGM-LS1, at Lagoa Salgada, Grândola, Portugal: A first report on pyrophyllite in a central stockwork. Boletín Sociedad Española Mineralogía, 17-1: 157-158.

Relvas, J.M.R.S., Tassinari, C.C.G., Munhá, J., Barriga, F.J.A.S. 2001. Multiple sources for ore-forming fluids in the Neves Corvo VHMS deposit of the Iberian Pyrite Belt (Portugal): strontium, neodymium and lead isotope evidence. Mineralium Deposita, 36: 416-427.

Relvas, J.M.R.S., Barriga, F.J.A.S., Pinto, A., Ferreira, A., Pacheco, N., Noiva, P., Barriga, G., Baptista, R., Carvalho, D., Oliveira, V., Munhá, J., Hutchinson, R. W. 2002. The Neves-Corvo deposit, Iberian Pyrite Belt, Portugal: Impacts and future, 25 years after the discovery. Society of Economic Geology Special Publication, 9: 155-176.

Relvas, J.M.R.S., Barriga, F.J.A.S., Ferreira, A., Noiva, P. C., Pacheco, N., Barriga, G. 2006a. Hydrothermal alteration and mineralization in the Neves-Corvo volcanic-hosted massive sulfide deposit, Portugal: I. Geology, mineralogy, and geochemistry. Economic Geology, 101: 791-804.

Relvas, J.M.R.S., Barriga, F.J.A.S., Longstaffe, F. J. 2006b. Hydrothermal alteration and mineralization in the Neves-Corvo volcanic-hosted massive sulfide deposit, Portugal: II. Oxygen, hydrogen, and carbon isotopes. Economic Geology, 101: 753-790.

Relvas, J.M.R.S., Barriga, F.A.S., Carvalho, J.R.S., Pinto, A.M.M., Matos, J.X., Rosa, C.J.P., Pereira, Z. 2011. Structure, stratigraphy and hydrothermal alteration at the Gavião orebodies, Aljustrel: reconstruction of a dismembered ore-forming system at the Iberian Pyrite Belt and implications for exploration. 11th Biennial SGA Meeting, Antofagasta, Chile, 772-774.

Ribeiro, A. 1984. Paleozóico - Tectónica. In: Oliveira, J. T. (coord.), Notícia explicativa da Folha 7, Carta Geológica de Portugal, escala 1:200,000. Lisboa, Serviços Geológicos de Portugal, p. 28-30 (in Portuguese).

Ribeiro, A., Quesada, C., Dallmeyer, R.D. 1990. Geodynamic evolution of the Iberian Pyrite Belt. In: Dallmeyer, R.D., Martínez García, E. (eds.). PreMesozoic Geology of Iberia. Springer, Berlin, 339-409.

Ribeiro, A.,Munhá, J.,Dias, R., Mateus, A., Pereira, E., Ribeiro, L., Fonseca , P., Araújo, A., Oliveira, J. T., Romão, J., Chaminé, H., Coke, C., Pedro, J. 2007. Geodynamic evolution of the SW Europe Variscides. Tectonics, Dec. 2007, 26(6), TC6009, http://dx.doi. org/10.1029/2006TC002958 (24 p.)

Rodríguez, R.M., Díez-Montes, A., Leyva, F., Matas, J., Almarza, J., Donaire, M. 2002. Datación palinoestratigráfica del volcanismo en la sección de la Ribera del Jarama (Faja Pirítica Ibérica, Zona Surportuguesa). Geogaceta, 32: 247-250. 
Rosa, C.J.P. 2007. Facies architecture of the Volcanic Sedimentary Complex of the Iberian Pyrite Belt, Portugal and Spain. $\mathrm{PhD}$ thesis, University of Tasmania, $357 \mathrm{p}$.

Rosa, D., Inverno, C., Oliveira, V., Rosa, C., 2006. Geochemistry and geothermometry of volcanic rocks from Serra Branca, Iberian Pyrite Belt, Portugal. Gondwana Research, 10: 328-339.

Rosa, C.J.P., McPhie, J., Relvas, J., Pereira, Z., Oliveira, T., Pacheco, N. 2008. Volcanic setting of the giant Neves Corvo massive sulfide deposit, Iberian Pyrite Belt, Portugal. Mineralium Deposita, 43: 449-466.

Rosa, C., McPhie, J., Relvas, J., 2009. The Felsic Volcanic Centres of Neves Corvo and Lousal Massive Sulfide Deposits in the Iberian Pyrite Belt. In: Williams, P.J. et al. (eds.), 10th Biennial SGA Meeting, Smart Science for Exploration and Mining, Townsville, Australia, Economic Geology Reserch Unit, James Cook University, vol. 1, 484-486.

Rosa, C.J.P., McPhie, J., Relvas, J. 2010a. Type of volcanoes hosting the massive sulfide deposits of the Iberian Pyrite Belt. Journal Volcanology Geothermal Research, 194: 107-126.

Rosa, C., Rosa, D., Matos, J., Relvas, J, 2010b. The volcanic-sedimentary sequence of the Lousal deposit, Iberian Pyrite Belt (Portugal). Geophysical Research Abstracts, EGU General Assembly, Vol. 12, EGU2010- 11000.

Rosa C, McPhie J, Relvas J, (2011) Sediment-matrix igneous breccias at the top contacts of felsic units in the IPB: implications for VHMS exploration. 11th SGA Biennial Meeting: Let's Talk Ore Deposits. Antofagasta, Chile. s2.6.5, 754-756.

Routhier, P., Aye, F., Boyer, C., Lécolle, M., Molière, P., Picot, P., Roger, G. 1980. Le ceinture sud-ibérique à amas sulfurés dans sa partie espagnole médiane. Mémoire du BRGM 94, 265 pp.

Sáez, R., Almodóvar, G.R., Pascual, E. 1996. Geological constraints on massive sulphide genesis in the Iberian Pyrite Belt. Ore Geology Reviews, 11: 429-451.

Sáez, R., Pascual, E., Toscano, M., Almodóvar, G.R. 1999. The Iberian type of volcano-sedimentary massive sulphide deposits. Mineralium Deposita, 34: 549-570.

Sánchez-España, J., Velasco, F., Boyce, A.J., Fallick, A. E. 2003. Source and evolution of ore-forming hydrothermal fluids in the northern Iberian Pyrite Belt massive sulphide deposits (SW Spain): evidence from fluid inclusions and stable isotopes. Mineralium Deposita, 38: 519-537.

Schermerhorn, L.J.G., 1971. An outline stratigraphy of the Iberian Pyrite Belt. Boletin Geologico y Minero, 82 (3/4): 239-268.

Schermerhorn, L.J.G., Zbyszewski, G., Veiga Ferreira, O., 1987, Notícia Explicativa da Folha 42-D (Aljustrel), Carta Geológica de Portugal, escala 1:50,000: Lisboa, Serviços Geológicos de Portugal, 55 p. (in Portuguese).

Schütz, W., Ebneth, J., Meyer, K.D. 1987. Trondhjemites, tonalites and diorites in the South Portuguese Zone and their relations to the vulcanites and mineral deposits of the Iberian Pyrite Belt. Geologische Rundschau, 76 (1): 201-212.

Silva, J.B., Oliveira, J.T., Ribeiro, A. 1990. South Portuguese Zone. Part VI. Structural outline. In: Dallmeyer, R.D., Martínez García, E. (eds.). PreMesozoic Geology of Iberia. Springer, Berlin, 348-362.

Simancas, J.F. 1983. Geología de la extremidad oriental de la Zona Sudportuguesa. Unpublished Doctoral Thesis, Univ. Granada, España, 439 pp.

Simancas, J.F., Carbonell, R., González Lodeiro, F., Pérez Estaún, A., Juhlin, C., Ayarza, P., Kashubin, A., Azor, A., Martínez Poyatos, D., Almodóvar, G.R., Pascual, E., R. Sáez, R., Expósito, I. 2003. Crustal structure of the transpressional Variscan orogen of SW Iberia: SW Iberia deep seismic reflection profile (IBERSEIS). Tectonics, 22 (6), 1062, 1-11 - 1-19.

Solomon, M., Tornos, F., Gaspar, O.C. 2002. A possible explanation for many of the unusual features of the massive sulfide deposits of the Iberian Pyrite Belt. Geology, 30: 87-90.

Solomon, M., Tornos, F., Large, R.R., Badham, J.N.P., Both, R.A., Khin Zaw. 2004. Zn-Pb-Cu volcanichosted massive sulfide deposits: Criteria for distinguishing brine pool- from black smoker-type sulfide deposition. Ore Geology Reviews, 25: 259-283.

Soriano C, Martí, J. 1999. Facies Analysis of VolcanoSedimentary Successions Hosting Massive Sulfide Deposits in the Iberian Pyrite Belt, Spain. Economic Geology, 94: 867-882.

Strauss, G.K., Madel, J., Fernández Alonso, F. 1977. Exploration practice for strata-bound volcanogenic sulphide deposits in the Spanish-Portuguese Pyrite Belt: Geology, geophysics, and geochemistry. In: Klemm, D.D., Schneider, H.J. (eds.). Time and stratabound ore deposits. Berlin, Springer-Verlag, p. 55-93.

Strauss, G.K., Beck, J.S. 1990. Gold mineralizations in the SW Iberian Pyrite Belt. Mineralium Deposita, 25: 237-245.

Thiéblemont, D., Pascual, E., Stein, G. 1998. Magmatism in the Iberian Pyrite Belt: petrological constraints on a metallogenetic model. Mineralium Deposita, 33: 98-110.

Tornos, F. 2006. Environment of formation and styles of volcanogenic massive sulfides: The Iberian Pyrite Belt. Ore Geology Reviews, 28: 259-307.

Tornos, F., Heinrich, C.A. 2008. Shale basins, sulfurdeficient ore brines, and the formation of exhalative base metal deposits. Chemical Geology, 247: 195-207.

Tornos, F., Spiro, B. 1999. The genesis of the shalehosted massive sulphides in the Iberian Pyrite Belt. In: Stanley, C.J. et al. (eds.). Mineral deposits: Processes to processing. Rotterdam, Balkema, p. 605-608.

Tornos, F., González-Clavijo, E., Spiro, B.F. 1998. The Filón Norte orebody (Tharsis, Iberian Pyrite Belt): a proximal low-temperature shale-hosted massive sulphide in a thin-skinned tectonic belt. Mineralium Deposita, 33: 150-169.

Tornos, F., Barriga, F., Marcoux, E., Pascual, E., Pons, J. M., Relvas, J., Velasco, F. 2000. The Iberian Pyrite Belt, in Large, R., Blundell, D. (eds.). Database on global VMS districts: CODES-GEODE, p. 19-52. 
Tornos, F., Casquet, C., Relvas, J.M.R.S. 2005. Transpressional tectonics, lower crust decoupling and intrusion of deep mafic sills: a model for the unusual metallogenesis of SW Iberia. Ore Geology Reviews, 27: 133-163.

Tornos, F., Solomon, M., Conde, C., Spiro, B. F. 2008. Formation of the Tharsis massive sulfide deposit, Iberian Pyrite Belt: Geological, lithogeochemical, and stable isotope evidence for deposition in a brine pool. Economic Geology, 103: 185-214.

Toscano, M., Sáez, R., Almodóvar, G.R. 1997. Multiscale fluid evolution in the Masa Valverde (Iberian Pyrite Belt): Evidence from fluid inclusions. [abs.]: Society of Economic Geologists Neves Corvo Field Conference, Abstracts and Program, p. 101.

Valenzuela, A., Donaire, T., Pin, C., Toscano, M., Hamilton, M., Pascual, E. 2011. Geochemistry and
$\mathrm{U}-\mathrm{Pb}$ Dating of felsic volcanic rocks in the Río TintoNerva unit, Iberian Pyrite Belt, Spain: crustal thinning, progressive crustal melting and massive sulphide genesis.Journal of the Geological Society, 168: 717-731.

Velasco, F., Sánchez-España, J., Boyce, A.J., Fallick, A. E., Sáez, R., Almodóvar, G.R. 1998. A new sulphur isotopic study of some Iberian Pyrite Belt deposits: evidence of a textural control on sulphur isotope composition. Mineralium Deposita, 34: 4-18.

Yamamoto, M., Kase, K., Carvalho, D., Nakamura, T., Mitsuno, C. 1993. Ore mineralogy and sulfur isotopes of the volcanogenic massive sulfide deposits in the Iberian Pyrite Belt. Resource Geology Special Issue, 15: $67-80$. 